\title{
Reports from the SNHS Annual Meeting
}

Regina, October 13-14, 1961

by Margaret Belcher, Secretary, Saskatchewan Natural History Society

The thirteenth annual meeting of the Saskatchewan Natural History Society was held in the Saskatchewan Museum of Natural History on Saturday, October 14, 1961, following a Friday evening executive meeting and a members' coffee party arranged by the Regina Natural History Society.

\section{BUSINESS SESSION}

Addresses of welcome were given by F. G. Bard, Director of the Saskatchewan Museum of Natural History, C. S. Brown, Director of the Conservation Branch of the Department of Natural Resources, and $R$. W. Nero, President of the S.N.H.S. The minutes of the last annual meeting were approved as circulated.

\section{Reports of Officers}

BUSINESS MANAGER - Frank Roy described the mailing of the Blue Jay which is looked after by a committee in Saskatoon. The fact that 1000 fewer magazines were mailed in September 1961 than in September 1960 was noted as a cause for concern. Christmas cards had been bought at $57 \&$ per box, to sell at $\$ 1.00$, and a combined renewal order form had been inserted in the Blue Jay at the cost of about $\$ 80$.

EDITOR - George F. Ledingham expressed pride in the contributions he had received for the Blue Jay during the past year, constituting 212 pages of published material. $\mathrm{He}$ thanked members for their contributions, and proposed that the following persons who have been assisting in the publication of the magazine be listed as "associate editors"-R. W. Nero, Joyce Dew, Margaret Belcher.

'TREASURER-Mrs. Grace Steele presented the financial statement printed in this issue, and reported one outstanding bill-\$85.95 for Blue Jay insert. Moved that a vote of thanks be given to Manley Callin for auditing the Society's books, and that we pay him $\$ 25.00$ as a contribution towards his expenses.
CORRESPONDING SECRETARY -Margaret Belcher reviewed correspondence arising from resolutions submitted after the annual and summer ineetings, reported registration of the Society under the Societies Act and affiliation with the Audubon Society of Canada, and acknowledged receipt of the D.N.R. Conservation grant of $\$ 1,000$. A letter from the Hon. Mr. Kuziak suggesting the marking of Prairie Dog colonies was discussed, and referred to the incoming executive for further consideration.

\section{Reports of Committees}

BLUE JAY SHOP_-Mrs. Elizabeth Cruickshank reported that the Shop had been open for regular hours 2:00 to 5:00 p.m.) from June 15September 8, and that 509 work hours had been paid for. Many people helped make the shop a success, especially George Dodd, shop treasurer, Connie Pratt, secretary, and Mrs. Grace Steele. In addition, the commissionaire at the Museim sold items from the counter outside regular Shop hours. $\mathrm{Mr}$. Dodd's financial report for the Shop showed net income of $\$ 1,041.32$ ( $22.5 \%$ of sales).

MEMBERSHIP - In the absence of Sylvia Halrison, who offered her resignation as chairman because of illness, G. F. Ledingham presented the membership report, showing a drop in membership of 500 during the past year (2923 in 1960; 2419 in 1961). Because it is necessary for the Membership Committee to work closely with the Treasurer, Dr. Ledingham had proposed to the executive that the Treasurer be the chairman of the committee, and this was approved. All members were urged to sell Blue Jays.

PUBLICITY-Doug Wade reported on news releases sent to weekly newspapers, T.V., etc.

CONSERVATION-Fred Bard reported on the following conservation projects: erection of martin houses; Canada Goose management program; Regina Waterfowl Park brief to city 
council and to the planning committee for the University of Saskatchewan in Regina; trip to rescue injured Trumpeter Swan from the Cypress Hills; Whooping Crane report of 40 birds in the wild this summer; proposed extension of the Wascana Game Preserve.

RESEARCH GRANTS COMMITTEE - Elmer Fox reported on origin of fund- $\$ 491.42$ left over from the A O. U. local committee's funds, plus accrued interest. No awards were made in 1960, but in 1961 two awards of $\$ 50$ were made to Bernard de Vries for his work on the flora of the Qu'Appelle and to Ronald and Donald Hooper for their studies of butterflies and moths in Saskatchewan. 'The balance of the research fund (October 1, 1961) is now $\$ 408.71$.

PUBLICATIONS-Stuart Houston reporte $\bar{x}$ that the main item for 1961 was the publication of Margaret Belcher's Birds of Regina. Special publications \#1 and \#2 have now been paid for by grants and sales, and profits from further sales wil! help to launch (1) the Blue Jay index, prepared by Joyce Dew, (2) the Birds of Athabasca (R. W. Nero), (3) Birds of the Qu'Appelle Valley (E. M. Callin).

\section{Reports of Local Societies}

MOOSE JAW - Current membership is 83 , including 20 juniors. Eight monthly meetings were held in the past year, with nine field trips, a potluck supper, and the Christmas Bird Count. Junior members have made a real contribution to the program.-F. Hill, President.

REGINA-Membership is 200, but the Society does not feel that it does enough for young people. Sponsoring the Audubon screen tours is a major project of the Club. Field trips included one with the Moose Jaw Society to Old Wives Lake, one to the Big Muddy with members of the Canadian Museums Association as guests, and trips to the Society's "Hidden Valley" sanctuary. - T. Gentles, President.

SASKATOON - There are 140 family memberships. Activities included Christmas Bird Count, members' night, slide programmes, Sunday early morning hikes, occasional
Saturday field trips, a fall outdoor meeting at Beaver Creek. The Saskatoon Society planned the summer ineeting of the S.N.H.S.-C. S. Houston, President.

PRINCE ALBERT-the membership is 33 . The chief projects of the club have been building up a series of nature slides for schools, and studying the Resources for Tomorrow conference papers. - T. Capusten, President.

\section{Report on the Special Refuge Fund}

G. F. Ledingham described the beginnings of the Sandhill Crane project as a publicity attraction for the A. O. U. meeting in Regina in 1959. Crop damage in that wet fall occasioned special study of the crane problem, and the S.N.H.S. recommended that the sanctuary be extended and lure crops planted. Latest proposal, made at the summer meeting this year, has been that the federal government sponsor a wildlife stamp to provide funds for refuges. Since the federal government feels that it cannot legislate for wildlife other than migratory birds, and since the provincial government has not given leadership, Dr. Ledingham urged that the S.N.H.S. act to establish a refuge fund. Moved that the S.N.H.S. inform the federal and provincial governments of this fund and its purpose, and that we write to the Secretariat of the Resources for Tomorrow conference about this project.

\section{PROGRAM}

1. Doug Wade conducted a picture quiz on birds of prey to show how difficult identification is, and spoke briefly on the need for publicizing hawks and owls legislation.

2. Series of nature slides were shown with comment by the following members - S. Houston, Mrs. Skinner, Tony Capusten, W. Riome, D. Wade, Gary Anweiler, Ross Lein, and R. W. Nero.

3. Illustrated lecture by Bruce McCorquodale, curator of paleontology, S.M.N.H., on the activities of his department during the past year. The discoveries of well-preserved remains of post-glacial forests, a huge mammoth tusk, and the partial remains of a 70 million year old mosasaur, a saurus with flippers, were described. 
4. Evening Lecture. Following the informal buffet dinner, the group met to hear Professor F. H. Edmunds, Head of the Department of Geology, University of Saskatchewan, speak on "Some Aspects of the Geology of the Sand Dunes of Lake. Athabasca." Dr. Edmunds showed a series of slides to illustrate the topography of the sand dunes, and to show members of his party in action. Since this is the same area in which Dr. Nero made some of his Lake Athabasca bird studies, members of the Society enjoyed the complementary picture given of the country presented by a geologist.

\section{RESOLUTIONS}

Resolved that the Saskatchewan Natural History Society commend the Department of Natural Resources on its pian to purchase a unit of land at the north end of Last Mountain Lake where our Society has had a continuing interest in the establishing of wildlife refuges. Resolved further that the Saskatchewan Natural History Society congratulate the Department for the interest it is taking in establishing a semiwilderness park in the Big Muddy country.

Resolved that the Saskatchewan Natural History Society urge the Federal Government authorities to renew their efforts in protecting the rare Trumpeter Swan in the Cypress Hills area. Recent reports of the removal or destruction of signs posting the area to protect the swans have been received with alarm.

Whereas the indiscriminate burning of brush or stubble during the nesting season causes untold suffering and death to both birds and other animals, be it resolved that this meeting take steps, in so far as they are able, to have such practices discontinued.

Resolved that the Saskatchewan Natural History Society express its appreciation to the Minister of Natural Resources, and through him to the Conservation Grants Committee, for the generous assistance received by the Society in the form of a Conservation Grant. This year's grant was especially designated for the publication of the Blue Jay, and it is obvious from our financial statement that the magazine could not have been published without it.

\section{ACKNOWLEDGMENTS}

Much of the burden of arranging for the meeting was shouldered for the Saskatchewan Natural History Society by members of the local Regina society and the staff of the Museum of Natural History. The Society acknowledges gratefully their assistance and hospitality.

On Friday evening a coffee party arranged by the Regina Natural History Society brought town and out-of-town members together for a friendly social hour following the executive meeting and the showing of films in the Auditorium. Mrs. Grace Steele, who convened the evening reception for the Regina group, appeared again in her role cf busy hostess the next day to make arrangements for morning coffee for members returning from a preconference bird hike and for the afternoon coffee "break."

The thoughtful arrangements made for the pleasure of our members by Mr. Fred Bard, Director of the Museum of Natural History, and his staff made the Museum a very acceptable headquarters for our annual meeting and allowed members who did not live in Regina a welcome opportunity to visit the Museum exhibits.

Finally, our thanks go to Mrs. Holly Wallace and her competent and gracious Reception Committee for taking care of registration throughout the conference.

\section{SASKATCHEWAN N A T U R A L HISTORY SOCIETY AWARDS}

The Cliff Shaw Memorial Award was given to John H. Hudson of Saskatoon. This award, in memory of Cliff Shaw, goes to a member of the Saskatchewan Natural History Society who makes a worthwhile contribution to the Blue Jay. In citing $\mathrm{Mr}$. Huason for this award, the Editor commended him for his interesting study of the geology and geography of the Old Man On His Back Plateau in the southwest corner of the province, and for recording new plants for Saskatchewan. Mr. Hudson is a research chemist by profession, but he is also a keen and competent amateur botanist. 
The Conservation Award for 1961 was given to Herb Moulding, Provincial Manager for Ducks Unlimited, Canada. This organization, in its efforts to maintain and restore wetlands, has done more for wetlands wildlife, we believe, than any other group in Saskatchewan. Thanks to their work there now exists a considerable body of information concerning the history of hundreds of key marshes in this area. This information provides a sound basis for wetlands management; but it also presents a sad picture of the enormous loss of this natural resource. We recognize that "D.U." is primarily interested in maintaining a harvestable supply of waterfowl, but marshes attract a wide variety of wildlife species in addition to ducks and geese. Each marsh restored by D.U. is in itself one more wilderness unit. On the prairies these units are vital to the well-being of all of us.

Mr. Moulding, a Regina resident, is also Chairman of the Regina

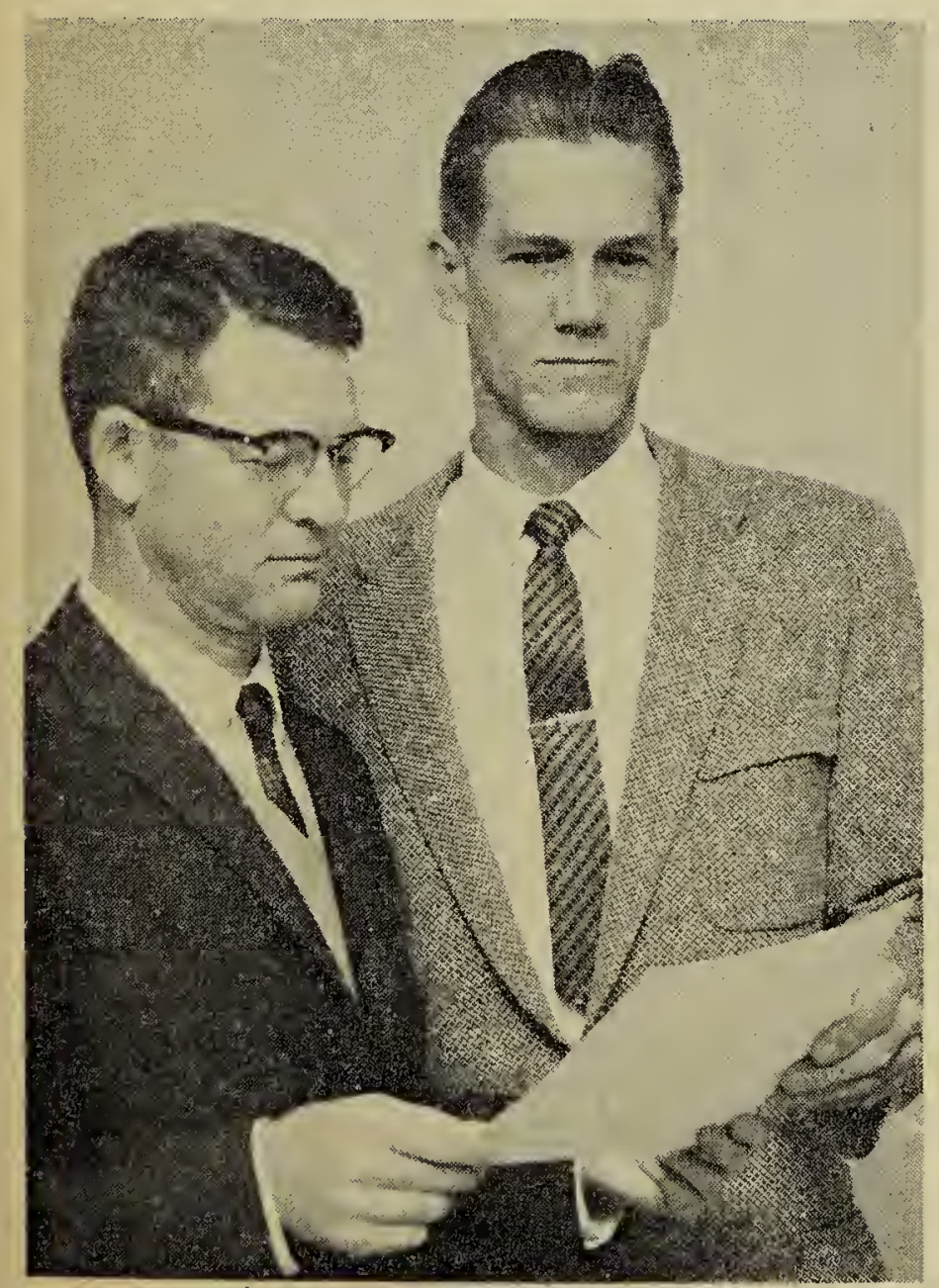

Leader-Post Photo

Past President R. W. Nero presenting the Conservation Award to H. Moulding of Ducks Unlimited.
Waterfowl Park Committee, an organization which is actively seeking permanent protection of the marsh habitat and associated wildlife on the Wascana Creek within the city limits of Regina. It is felt that this unit of marshland will serve to acquaint the public with the values of this unique type of habitat.

\section{LIST OF PERSONS REGISTERED}

ABERNETHY: R. Stueck. ESTEVAN: Ross Lein. HANLEY: R. W. EImore. HAZELCLIFFE: J. Provick. INDIAN HEAD: Mr. and Mrs. K. Skinner, Joan and Kathy Skinner, Betty Watson, Mrs. Hilda Newton. KINDERSLEY: E. Johnson. MCLEAN: Mrs. H. Bray. MELVILLE: Gary Anweiler. MOOSE JAW: Mrs. F. B. Taylor, Miss E. S. Curtis, W. Riome, Dr. and Mrs. D. M. Ewart, Judy, Doug and Patty Ewart, Patricia MacKenzie, Mrs. Dorothy Rhodes, Michael Rhodes, John Horton, Mrs. Vesta Humphreys, F. Hill, Gordon Morley, Molly Ritchie, Mrs. Freda Walker. OXBOW: Mrs. K. Paton. PRINCE ALBERT: Mr. and Mrs. A. Capusten, J Capusten, H. Towell. REGINA: Dr. and Mrs. R. W. Nero, Dr. and Mrs. G. F. Ledingham, Mrs. Evelyn Wiesbrot, Mrs. Gwen Mansbridge, Marguerite Robertson, Christine MacDonald, D. Gilroy, Mr. and Mrs. D. Wade, Alan Wade, Joyce Dew, Ada Young, Mrs. G. H. Mullin, Mr. and Mrs. A. Nilsen, Mrs. H. H. Sills, Margaret Belcher, Connie Pratt, L. T. Carmichael, Annie Peart, Mrs. Gertrude Smith, Mrs. Grace Steele, F. G. Bard, V. Wilshire, H. Moulding, T. Gentles, Pearl Guest, Mrs. A. Blakeney, Mrs. Elizabeth Cruickshank, C. S. Brown, Mrs. H. A. Croome, Dorothy Eley, Lucy Eley, Mr. and Mrs. F. Brazier, Bill Fleming, G. W. Stewart, T. Harper, G. Dodd, Lucy Murray, Maureen Rever, B. McCorquodale, E. L. Paynter, Mr. and Mrs. R. Harrison, Elizabeth Parkin, Rick Sanderson. SASKATOON: Dr. and Mrs. S. Houston, Stanley Houston, Mrs. J. Pepper, Ronald and Phyllis Pepper, F. Roy, R. Pravda, Mr. and Mrs. W. Richards, R. M. Bremner. SKULL CREEK: Mrś. Lina Benetto, S. A. Mann. TISDALE: E. Baines. WOLSELEY: D. Hayward. ZEHNER: George Chopping. 